\title{
Antioxidant, Enzyme Inhibitory and Anti-Obesity Potential of Sorrel Calyx Extracts in 3T3-L1 Adipocytes
}

\author{
E. Mutai, R. Sunkara, Jorge Vizcarra, L. T. Walker, M. Verghese \\ Alabama A\&M University, Normal, AL, USA \\ Email: martha.verghese@aamu.edu
}

Received 18 January 2015; accepted 28 March 2015; published 1 April 2015

Copyright (C) 2015 by authors and Scientific Research Publishing Inc.

This work is licensed under the Creative Commons Attribution International License (CC BY). http://creativecommons.org/licenses/by/4.0/

(c) (i) Open Access

\begin{abstract}
Hibiscus sabdariffa L. (sorrel) has been widely used in the development of tropical beverages and folk medicine. This study's objective was to investigate the anti-obesity potential of sorrel calyx extracts (methanol and water) on 3T3-L1 adipocyte cells. Phytochemical content, antioxidant potential as DPPH (1, 1-Diphenyl-2-picrylhydrazyl) radical scavenging activity and ferric reducing antioxidant power (FRAP) and enzyme ( $\alpha$-glucosidase, $\alpha$-amylase, and pancreatic lipase) inhibitory activities were determined in sorrel methanol extracts (SME) and sorrel water extracts (SWE). Effect of SWE and SME on lipid accumulation, lipolysis and apoptosis were tested in 3T3-L1 adipocyte differentiation and maintenance stage of cells at selected concentrations $(200-1000 \mu \mathrm{g} / \mathrm{ml})$ was studied. The total phenolic (GAE $\mathrm{mg} / \mathbf{1 0 0 g}$ dry weight) and total flavonoid (mg catechin equi/ $100 \mathrm{~g}$ dry weight) contents in SME and SWE were 158.31 and 317.27 and 90.77 and 100.08. DPPH\% inhibition (IC-50-mg/ml) and FRAP (mmol Fe [II]/100g dry weight) were 0.82 and 0.33 and 1799.13 and 2296.38 for SWE and SME, respectively. SME and SWE inhibited $\alpha$-glucosidase, $\alpha$-amylase, and pancreatic lipase activities by more than $40 \%$ at $4 \mathrm{mg} / \mathrm{ml}$. Significant $(p<0.05)$ reduction in lipid accumulation and increased glycerol release in 3T3-L1 cells was observed at concentrations ranged from $600 \mathrm{mg} / \mathrm{ml}$ of both extracts. Treating cells with SME-1000 $\mu \mathrm{g} / \mathrm{ml}$ at differentiation resulted inhibition $(p<0.05)$ of lipid accumulation by $45 \%$ compared to untreated cells. Highest $(p<0.05)(35 \%)$ decrease in triglyceride content as well as higher glycerol release was seen in cells exposed to SME at the differentiation stage. Sorrel extracts induced apoptosis in adipocytes at higher concentrations with prominent effect of treating cells at differentiation stage. The results of this study showed effect of sorrel extracts in reduction of lipid accumulation and increase in lipolysis of 3T3-L1 cells.
\end{abstract}

\section{Keywords}

Sorrel, Phytochemicals, Adipogenesis, Adipocytes, Lipolysis, Antioxidant

How to cite this paper: Mutai, E., Sunkara, R., Vizcarra, J., Walker, L.T. and Verghese, M. (2015) Antioxidant, Enzyme Inhibitory and Anti-Obesity Potential of Sorrel Calyx Extracts in 3T3-L1 Adipocytes. Food and Nutrition Sciences, 6, $452-465$. 


\section{Introduction}

Obesity has become one of the greatest threats to global health with studies showing a strong association between obesity and increased risk of developing metabolic disorders such as cardiovascular diseases, hypertension, and diabetes [1]. Obesity is characterized by an increase in the level of lipid stores, changes in systemic energy and adipocyte metabolism [2]. The dramatic increase of obesity epidemic in the recent past is as a result of excess adipose tissue resulting from both hypertrophy and hyperplasia of adipocyte cells [3]. Hyperplasia results in the formation of new adipocytes from precursor cells, the preadipocytes while hypertrophy, leads to increase in lipid accumulation in the adipocytes [4]. In recent years, the exploration of natural compounds for the treatment of obesity and development of safe anti-obesity drugs has dramatically increased [5]. Natural bioactive components such as plant extracts have been found to contain medicinal properties such as potential for inducing apoptosis and inhibiting adipogenesis in adipocyte cells [6].

Development of obesity is linked with complications in lipid metabolism and oxidative stress. A novel strategy currently being explored in the treatment of obesity is the development of inhibitors of nutrient digestion and absorption, with the aim of reducing energy intake through gastrointestinal mechanisms [7] [8]. The enzymes involved in lipid metabolic pathways represent a rich pool of potential therapeutic targets for obesity and other metabolic disorders [9]. Dietary lipids are the major sources of excess calories, and therefore, inhibition of triglyceride (TG) digestion provides a new strategy for the reduction of fat absorption [10] [11]. Pancreatic lipase (PL) is the major lipid digesting enzyme that plays a key role in the efficient digestion of triglycerides and is also responsible for hydrolysis of $50 \%-70 \%$ of total dietary fats [7]. PL inhibition is one of the most widely studied mechanisms for treatment of obesity [12].

High consumption of carbohydrate is another factor for increased fat deposition because excess carbohydrates are converted into fats in the body. Natural bioactive compounds shown to inhibit carbohydrate hydrolyzing enzymes such as $\alpha$-glucosidase have been recognized as potential therapeutic targets for modulation of postprandial hyperglycemia in type 2 diabetes mellitus patients [13] [14]. Inhibitors of $\alpha$-glucosidase enzyme can reduce uptake of dietary carbohydrate, suppress postprandial hyperglycemia, and therefore, may be useful in treating patients with diabetes and/or obesity [15]. A number of $\alpha$-glucosidase inhibitors such as acarbose and voglibose interfere with the activity of carbohydrate-digesting enzymes delaying glucose absorption [16].

There has been considerable interest in the investigation of the anti-obesity effects of natural products. Existing evidence has shown that phytochemicals exert anti-obesity effects through regulation of various metabolic pathways, including lipid absorption, the intake and expenditure of energy, the increase of lipolysis, and the decrease in proliferation of adipocyte cells [17]. Hibiscus sabdariffa (sorrel), is a member of the Malvaceae family and an annual tropical plant native to India and Malaysia [18]. Hibiscus sabdariffa L. calyx extracts have been used as traditional medicine against hypertension, pyrexia, inflammation, and cancer due to the presence of various bioactive components [19]. Sorrel extracts contain various phytochemicals that may have inhibitory effects on adipocyte differentiation and therefore the objective of this study was to study anti-obesity effects of sorrel calyx extracts on 3T3-L1 adipocyte cells.

\section{Materials and Methods}

\subsection{Preparation of Sorrel Extracts}

Dried sorrel calyces were purchased from a local health store (Huntsville AL, USA). They were ground to fine powder using an electric blender (Laboratory blender, Warring commercial, Torrington, CT, USA). Phytochemical extracts were prepared in $80 \%$ methanol and hot water. Five grams of sample was extracted in $100 \mathrm{ml}$ of $80 \% \mathrm{me}-$ thanol and concentrated in rotary evaporator (Safe aire, Fisher Hamilton, Gaithersburg, MD, USA). For water extraction, $20 \mathrm{~g}$ of sample was extracted with $100 \mathrm{ml}$ of water at $100^{\circ} \mathrm{C}$ for one hour and concentrated. The concentrates were stored at $-20^{\circ} \mathrm{C}$ until further analysis [20].

\subsection{Determination of Total Phenolics, Flavonoids and Anthocyanins}

The total phenolic content was determined according to the method of Singleton et al. (1999) [21] with modifications. Briefly, Sorrel extracts $(12.5 \mu \mathrm{l})$ were oxidized with $12.5 \mu \mathrm{L}$ of Folin Ciocalteau reagent and incubated for 5 minutes, neutralized by $125 \mu$ of $7 \% \mathrm{NaCO}_{3}$ at room temperature for 90 minutes. Absorbance was read at $750 \mathrm{~nm}$ using a microplate reader (Synergy HT, Bio Tek Instruments, Winooski, VT, USA). The total phenolic 
content was expressed as mg GAE/100g dry weight.

The total flavonoid content was determined according to the method of Kim et al. (2003) [22]. Appropriate dilutions of sorrel samples were mixed with $7.5 \mu \mathrm{L}$ of $5 \% \mathrm{NaNO}_{2}$ solution and $15 \mu \mathrm{L}$ of $10 \% \mathrm{AlCl}_{3}$. The mixture was incubated at room temperature for 5 minutes before adding $50 \mu \mathrm{L}$ of $1 \mathrm{M} \mathrm{NaOH}$ and $40 \mu \mathrm{L}$ of distilled water. The absorbance was read at $510 \mathrm{~nm}$ in microplate reader.

The total anthocyanins content was determined in duplicate using the $\mathrm{pH}$ differential method [23]. Absorbance was read at $520 \mathrm{~nm}$ and $700 \mathrm{~nm}$ in buffers at $\mathrm{pH} 1.0$ and 4.5, using a microplate reader (Synergy HT, Bio Tek Instruments, Winooski, VT, USA). The concentration was determined using monomeric anthocyanin pigment

$$
\mathrm{Mg} / 100 \mathrm{mg}=[A \times M W \times 1000] /[e X C]
$$

where $A=(\mathrm{A} 520 \mathrm{~nm}-\mathrm{A} 700 \mathrm{~nm}) \mathrm{pH} 1.0-(\mathrm{A} 520 \mathrm{~nm}-\mathrm{A} 700 \mathrm{~nm}) \mathrm{pH} 4.5 ; M W$ is the molecular weight of cyanidin-3-glucoside (449.2 g/mol), $C$ - concentration of sample; $e X$, is the molar extinction coefficient-26,900.

\subsection{Determination of 1,1-Diphenyl-2-Picrylhydrazyl (DPPH) Radical-Scavenging Activity}

Free radical scavenging activity was determined by following modified method of Brand-Williams, Cuvelier \& Berset (1995) [24]. Briefly, $40 \mu \mathrm{L}$ of appropriately diluted concentrations of sorrel extracts were added to 200 $\mu \mathrm{L}$ of $0.1 \mathrm{mM}$ 2,2-Diphenyl-1-picrylhydrazyl (DPPH) in methanol. Absorbance was measured at $517 \mathrm{~nm}$ at 90 minutes after incubating at room temperature (Synergy HT, Bio Tek Instruments, Winooski, VT, USA).

\subsection{Determination of Ferric Reducing Antioxidant Power (FRAP)}

The FRAP assay was performed according to Benzie \& Strain (1999) [25]. Briefly, $10 \mu \mathrm{L}$ of known dilutions of sorrel extracts were mixed with $200 \mu \mathrm{L}$ of FRAP reagent and incubated for 10 minutes at $37^{\circ} \mathrm{C}$. Change in absorbance was measured at $593 \mathrm{~nm}$ (Synergy HT, Bio Tek Instruments, Winooski, VT, USA) and the results are expressed as $\mathrm{mmol} \mathrm{Fe}^{2+} / \mathrm{g}$ dry weight.

\subsection{Enzyme Inhibition Assays}

The inhibition of pancreatic lipase (PL) (in-vitro) was determined using $p$-nitrophenyl butyrate ( $p$-NPB) as a substrate [26]. A stock solution (1mg/1ml) of PL was prepared in $0.1 \mathrm{mM}$ potassium phosphate buffer (pH 6.0). SME and SWE at different concentrations were pre-incubated with enzyme for 1 hour in a potassium phosphate buffer ( $0.1 \mathrm{mM}$, pH 7.2, combined with $0.1 \mathrm{ml}$ Tween 80 ). Subsequently, $5 \mu \mathrm{l}$ of substrate ( $25 \mathrm{mM}$ pNB in Dimethylformamide (DMF) was added and incubated for 5 minutes at $30^{\circ} \mathrm{C}$. The amount of 2, 4-dinitrophenol released in the reaction was measured at 360nm in microplate reader (Synergy HT, Bio Tek Instruments, Winooski, VT, USA).

Various concentrations $(0.2-4 \mathrm{mg} / \mathrm{ml})$ of SWE and SME, and $50 \mu \mathrm{l}$ of $0.02 \mathrm{M}$ sodium phosphate buffer (pH 6.9 with $0.006 \mathrm{M}$ sodium chloride) containing $\alpha$-amylase solution (4 units $/ \mathrm{ml}$ ) were incubated at $25^{\circ} \mathrm{C}$ for 10 minutes. After pre-incubation, $50 \mu \mathrm{l}$ of $1 \%$ starch solution was added and incubated for another $10 \mathrm{~min}$. Reaction was terminated by the addition of $100 \mu \mathrm{l}$ of dinitrosalicylic acid color reagent on steam for 5 minutes. After cooling room temperature, mixture was diluted with distilled water and absorbance read at $540 \mathrm{~nm}$ (Synergy HT, Bio Tek Instruments, Winooski, VT, USA).

The $\alpha$-glucosidase enzyme inhibitory assay was performed in a 96 well plate as described by kim et al., 2010 [27] with slight modifications. A $50 \mu \mathrm{l}$ of various concentrations of SME and SWE, and $100 \mu \mathrm{l}$ of containing $\alpha$-glucosidase solution (1.0 U/ml in $0.1 \mathrm{M}$ phosphate buffer ( $\mathrm{pH} 6.9)$ ) were incubated at $25^{\circ} \mathrm{C}$ for $10 \mathrm{~min}$. After pre-incubation, $50 \mu \mathrm{l}$ of $5 \mathrm{mM}$ p-nitrophenyl- $\alpha$-D-glucopyranoside was added to each well and incubated at for $5 \mathrm{~min}$ and absorbance was read at $405 \mathrm{~nm}$ (Synergy HT, Bio Tek Instruments, USA).

Enzyme inhibitory activity was calculated as follows:

$$
\text { Inhibitory activity }(I \%)=[\text { Abs. enzyme }- \text { Abs. extract }] /[\text { Abs. enzyme }] \times[100]
$$

\subsection{Cell Culture and Differentiation}

3T3-L1 mouse embryo fibroblasts were obtained from American Type Culture Collection (Manassas, VA, USA). Preadipocyte cells were grown in Dulbecco's Modified Eagle Medium (DMEM) containing 10\% calf bovine se- 
rum (CBS) and $1 \mathrm{mM}$ sodium pyruvate. For standard adipocyte differentiation, cells were treated with $10 \%$ fetal bovine serum (FBS), $10 \mu \mathrm{g} / \mathrm{mL}$ insulin, $1 \mu \mathrm{M}$ dexamethasone, and $0.5 \mu \mathrm{M}$ 3-isobutyl-1-methyl-xanthine for 48 hours. The cells were then maintained in a maintenance media containing $10 \%$ FBS and $10 \mu \mathrm{g} / \mathrm{ml}$ insulin for additional 4 - 6 days. Various concentrations $(100-1000 \mu \mathrm{g} / \mathrm{ml})$ of SME and SWE were added to media at differentiation and maintenance stages of cells to evaluate the anti-obesity properties. Cells that were not treated with extracts served as control.

\subsection{Cell Viability Assay}

Cell respiration as an indicator of cell viability and proliferation was determined using a mitochondrial-dependent reduction of 3-(4,5-dimethylthiazol-2-yl)-2,5-diphenyl tetrazolium bromide (MTT) to formazan using a commercial assay kit (Abnova, Walnut, CA, US) according to the manufacturer's instructions and absorbance read at $490 \mathrm{~nm}$ in a plate reader (Bio-Tek Synergy HT, Winooski, VT, US) to determine the concentration of formazan which is proportional to the number of live cells

\subsection{Oil Red O Staining and Determination of Lipid Content}

Cells were stained with Oil Red O (ORO) as described by Suryawan \& Hu (1993) [28]. Culture dishes were washed with PBS, fixed with $10 \%$ formalinand stained with a filtered ORO solution (0.5 grams of ORO in 100 $\mathrm{mL}$ of isopropyl alcohol) for 30 minutes. Cells were washed twice and visualized. Digital images were obtained by Nikon CT 120 microscope and photographs were taken by SPOT 2.0 digital camera. Stained cells were air dried, dissolved in isopropanol and absorbance was measured at $520 \mathrm{~nm}$ [27].

\subsection{Lipolysis, Triglyceride Content and Glycerol-3-Phosphate Dehydrogenase (GPDH) Activity}

Glycerol release was used to assess the lipolytic effect of sorrel extracts on 3T3-L1 adipocyte cells according to the glycerol cell-based assay kit (Abnova, Walnut, CA, USA). The glycerol was quantified at an absorbance of $540 \mathrm{~nm}$ in a microplate reader (Bio-Tek Synergy HT, Winooski, VT, US). The amount of glycerol released was calculated by the equation of glycerol standard curve. Cellular TG contents were measured using a commercial TG assay kit (Abnova, Walnut, CA, USA). The GPDH assay was performed using a spectrophotometric method for determination of the disappearance of $\beta$-nicotinamide adenine dinucleotide during GPDH-catalyzed reduction of dihydroxyacetone-3-phosphate using a commercial GPDH activity assay kit (Clontech labs, Mountain View, CA, USA).

\subsection{Apoptosis Assay}

A Cellular DNA Fragmentation kit was used (Roche, Indianapolis, IN, US) to determine extent of apoptosis. Cells grown in 96-well plates, were treated with sorrel extracts for 24 hours, and assayed as per the manufacturer's instructions.

\subsection{Statistical Analysis}

All experiments were performed in triplicates. Results are presented as means \pm SEM. ANOVA was used to determine any significant differences among the treatment groups. The means were separated using Tukey's Studentized Range Test at $\mathrm{P}<0.05$ (SAS 9.1).

\section{Results}

\subsection{Phytochemical Content Antioxidant Activity of Sorrel Calyx Extracts}

Phytochemical content in extracts were varied between types of extractions (Table 1). Water extraction of sorrel yielded higher $(\mathrm{p}<0.05)$ total phenolic content $(317.27 \mathrm{mg}$ GAE/100g) compared to SME (158.31 mg GAE/ $100 \mathrm{~g})$. However, method of extraction did not show significant differences in flavonoid content. Total flavonoid content determined as catechin equivalents was higher (100.08 mg CE/100g) in SWE. However, anthocyanin content was eight times higher in SME compared to SWE (88.77 mg/100mg). 
Table 1. Polyphenols, flavonoid and anthocyanin contents of sorrel methanol and water extracts.

\begin{tabular}{cccc}
\hline Sorrel & Polyphenols $(\mathbf{m g ~ G A E} / \mathbf{1 0 0 g})$ & Flavonoids $(\mathbf{m g} \mathbf{C E} / \mathbf{1 0 0 g})$ & Anthocyanins $(\mathbf{m g} / \mathbf{1 0 0 m g})$ \\
\hline SME & $158.31 \pm 24.56^{\mathrm{b}}$ & $90.77 \pm 3.29^{\mathrm{a}}$ & $88.77 \pm 4.17^{\mathrm{a}}$ \\
SWE & $317.27 \pm 34.58^{\mathrm{a}}$ & $100.08 \pm 13.77^{\mathrm{a}}$ & $10.06 \pm 4.50^{\mathrm{b}}$ \\
\hline
\end{tabular}

SME-sorrel methanol extracts; SWE-sorrel water extracts; GAE: Gallic Acid Equivalents; CE: Catechin Equivalents. Values are Mean \pm SD; $\mathrm{n}=3$.

${ }^{\mathrm{ab}}$ Values not sharing common superscript are significantly different $(\mathrm{p}<0.05)$ using Tukey's studentized range test.

Antioxidant potential analyzed as DPPH radical scavenging activity and ferric reducing potential were shown in Table 2. Highest antioxidative activity was found in SWE. DPPH radical inhibition was increased from 8\% $72 \%$ with an increase in concentration of SWE from 0.02 to $0.83 \mathrm{mg} / \mathrm{ml}$. More reduction in DPPH radical was observed in SWE ( $\left.\mathrm{IC}_{50}-0.33 \mathrm{mg} / \mathrm{ml}\right)$ compared to SME $\left(\mathrm{IC}_{50}-0.82 \mathrm{mg} / \mathrm{ml}\right)$. Ferric reducing potential of SWE extracts was 1.3 times higher than that of SME.

\subsection{Anti-Lipase Activity of Sorrel Calyx Extracts}

The ability of sorrel extracts to inhibit pancreatic lipase activity in-vitro was investigated and results are shown in Figure 1. Anti-lipase activity was found to be similar in both extracts. Inhibition of lipase activity (3\% - 46\%) was increased with increase in concentrations $(0.05-4 \mathrm{mg} / \mathrm{ml})$ of extracts. The percentage of lipase inhibition remained constant at concentrations of $1-4 \mathrm{mg} / \mathrm{ml}$ for both SME and SWE. Both extracts exhibited moderate (>38\%) inhibition of lipase activity at $1 \mathrm{mg} / \mathrm{ml}$.

\section{3. $\alpha$-Glucosidase and $\alpha$-Amylase Inhibitory Activities}

SME and SWE exhibited higher inhibition of both $\alpha$-glucosidase (Figure 2) and $\alpha$-amylase (Figure 3) activities in a concentration dependent manner. Incubation with SME resulted in a higher percent (78\%) of inhibition of $\alpha$-glucosidase activity at $4 \mathrm{mg} / \mathrm{ml}$ compared to SWE (42\%). Both extracts exhibited similar inhibition (35\%) of enzyme activity at concentrations ranging from $0.2-0.75 \mathrm{mg} / \mathrm{ml}$. Inhibitory potential of $\alpha$-glucosidase enzyme by SWE remained constant (30\% - 40\%) after $1 \mathrm{mg} / \mathrm{ml}$. A higher inhibition of $\alpha$-amylase activity was seen with an increase of SME concentrations ranging from $0.2-2 \mathrm{mg} / \mathrm{ml}$. However, there was a minimal increase in inhibition of $\alpha$-amylase with concentrations of SME ranging from $2-4 \mathrm{mg} / \mathrm{ml}$. SWE exhibited a lower percentage (38.8\%) of inhibition of $\alpha$-amylase activity at $4 \mathrm{mg} / \mathrm{ml}$ compared to SME (52.3\%) at the same concentration.

\subsection{Effects of Sorrel Extracts on Lipid Accumulation}

Accumulation of excess energy as triglycerides in adipocytes was analyzed quantitatively and qualitatively with Oil Red O staining. The cells were treated with different concentrations (200 - $1000 \mu \mathrm{g} / \mathrm{ml})$ at the differentiation and maintenance stages. The Oil Red O staining of cells revealed that SME and SWE suppressed lipid accumulation, by showing less accumulation of lipid droplets (Figure 4). The highest lipid accumulation was observed in untreated differentiated cells indicating excess storage cytoplasmic triglycerides (Figure 4(b)) after 6 days. Treatment of 3T3-L1 adipocyte cells with $200 \mu \mathrm{g} / \mathrm{ml}$ and $1000 \mu \mathrm{g} / \mathrm{ml}$ of SME and SWE decreased lipid accumulation and led to fewer lipid accumulated cells as shown in Figures 4(c)-(f) respectively. Quantitative analysis of Oil Red O staining exhibited an inhibition of lipid accumulation by sorrel extracts in a concentration-dependent manner (Figure 5). Significant $(\mathrm{p}<0.05)$ reduction in lipid accumulation at differentiation stage was observed in cells treated with SME at $400 \mu \mathrm{g} / \mathrm{ml}$. Whereas; SWE resulted in significant reductions in lipid content at $600 \mu \mathrm{g} / \mathrm{ml}$ at differentiation stage compared to control untreated adipocytes. Incubation with extracts resulted in a significant reduction in lipid accumulation at concentrations above $800 \mathrm{~g} / \mathrm{ml}$ compared to untreated cells. Highest $(\mathrm{p}<0.05)$ reduction $(45 \%)$ in lipid content was seen in cells treated with SME at a concentration of $1000 \mu \mathrm{g} / \mathrm{ml}$ at the differentiation stage. After incubation with SME-1000 $\mu \mathrm{g} / \mathrm{ml}$ at differentiation stage, lipid reduction was significantly higher in cells treated at both stages and SME at $800 \mu \mathrm{g} / \mathrm{ml}$ treated at both stages. The percent lipid content decreased from $98.2 \%$ - 63.7\% with the highest reduction in cells treated with SME at a concentration of $1000 \mu \mathrm{g} / \mathrm{ml}$ at the maintenance stage. SME was more effective in reducing lipid accumulation in treated cells compared to SWE. 


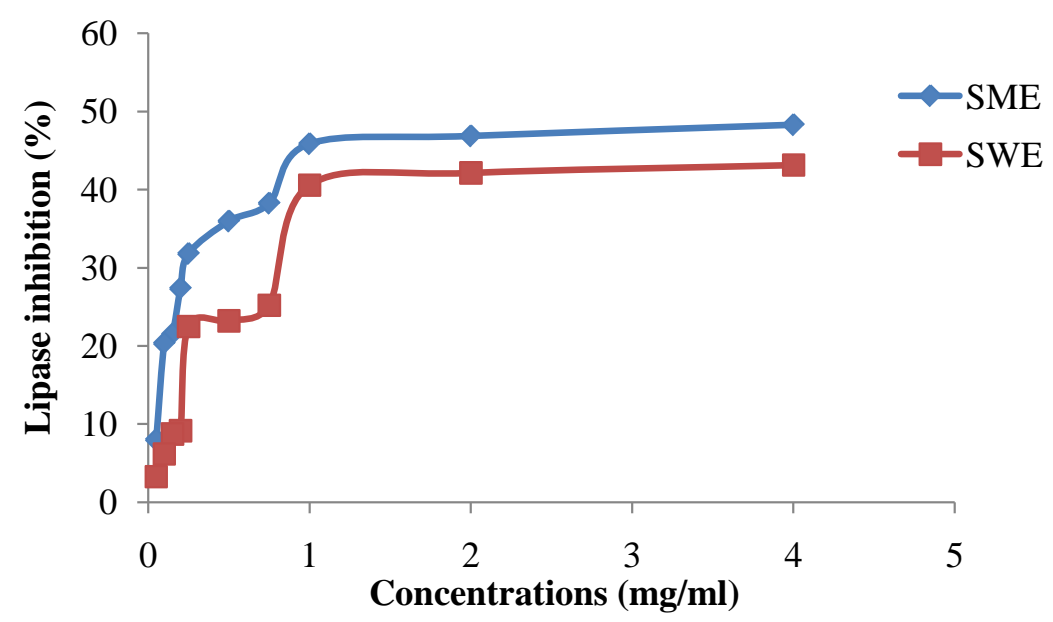

Figure 1. Inhibition of pancreatic lipase activity by sorrel methanol (SME) and water extracts (SWE).

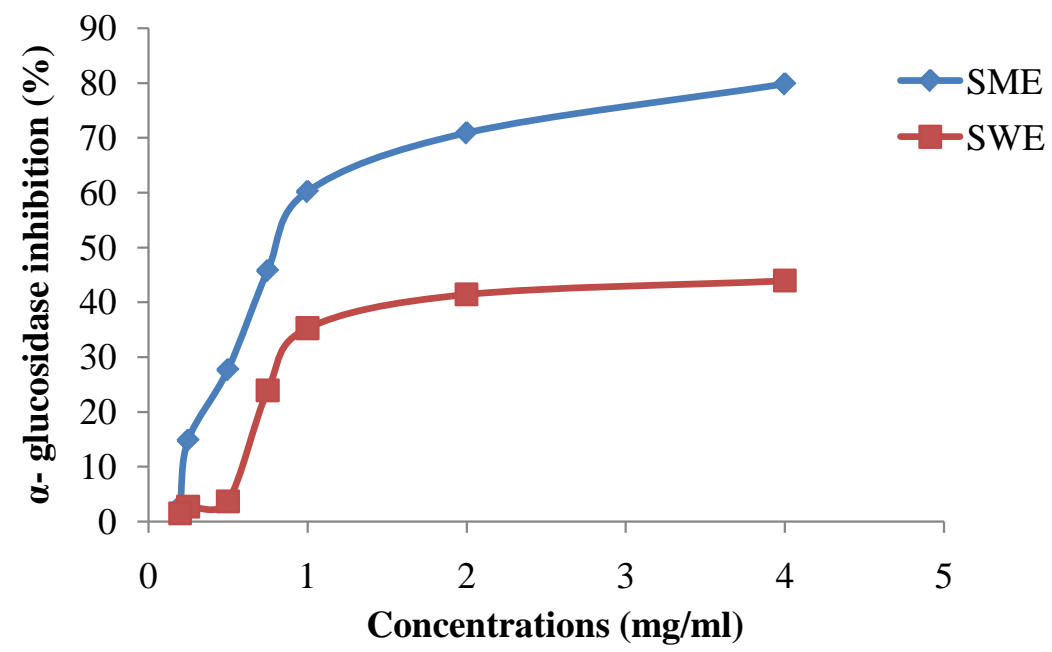

Figure 2. Inhibition of $\alpha$-glucosidase activity by sorrel methanol (SME) and water extracts (SWE).

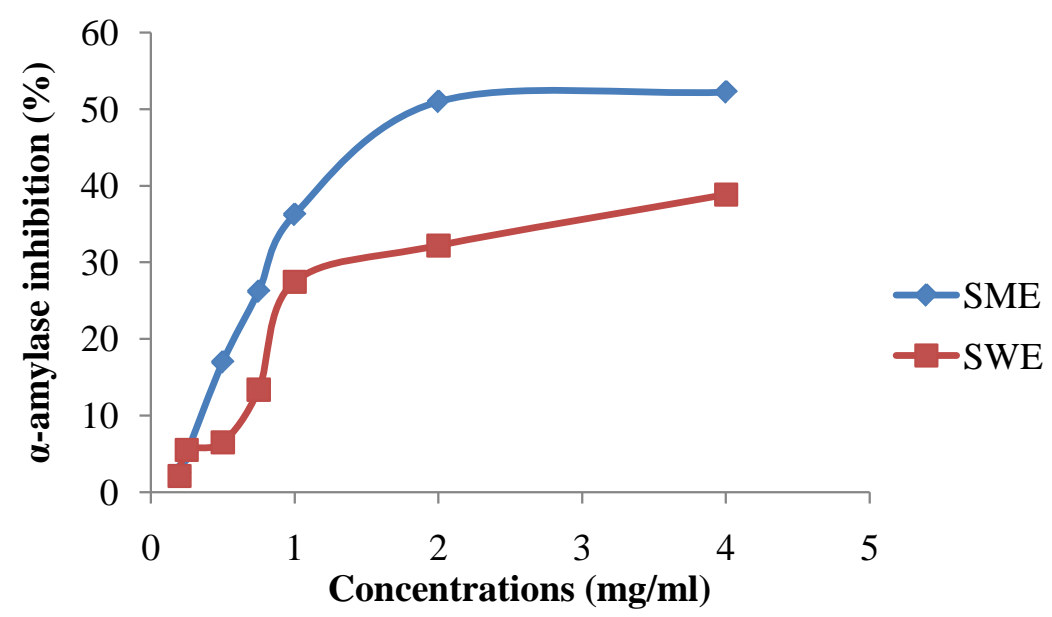

Figure 3. Inhibition of $\alpha$-amylase activity by sorrel methanol extract (SME) and sorrel water extract (SWE). 


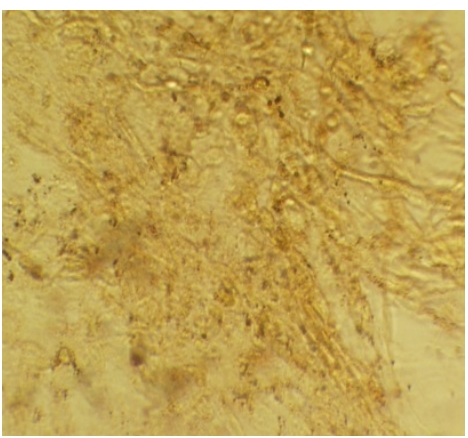

(a)

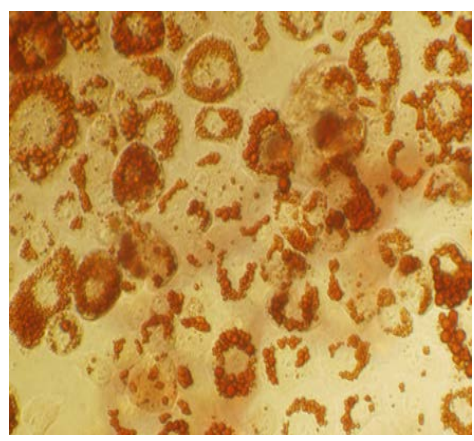

(b)

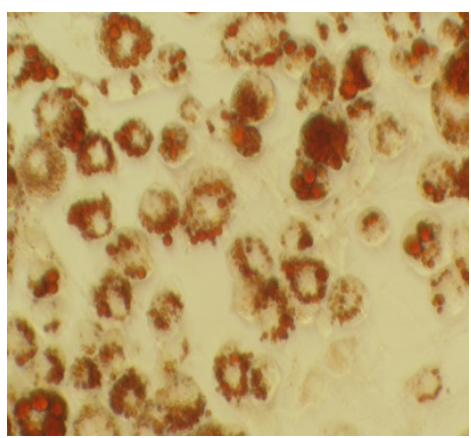

(c)

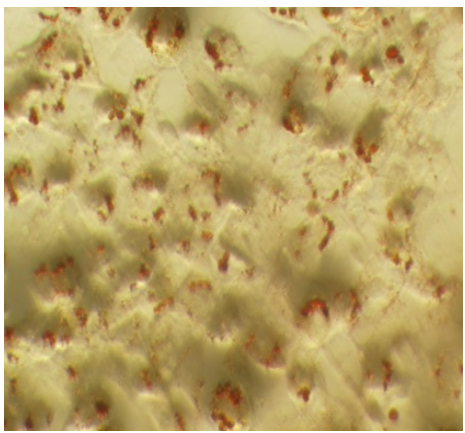

(d)

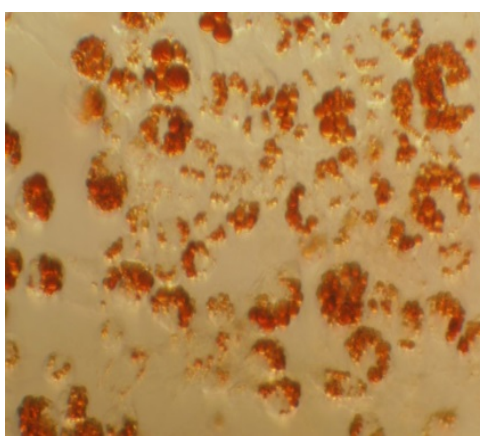

(e)

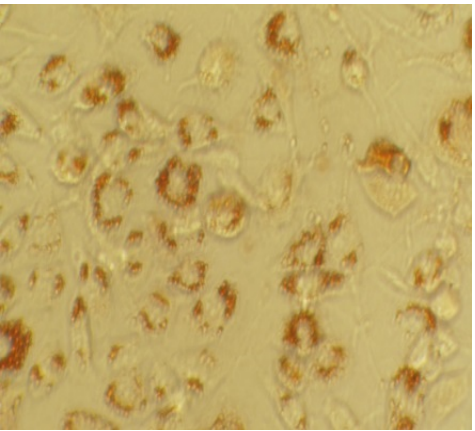

(f)

Figure 4. Oil Red O staining of 3T3-L1 cells treated with sorrel methanol extracts (SME). (a) Control (undifferentiated cells); (b) Control (untreated differentiated cells) (c) SME $200 \mu \mathrm{g} / \mathrm{ml}$; (d) SME $1000 \mu \mathrm{g} / \mathrm{ml}$; (e) SWE $200 \mu \mathrm{g} / \mathrm{ml}$; (f) SWE $1000 \mu \mathrm{g} / \mathrm{ml}$.

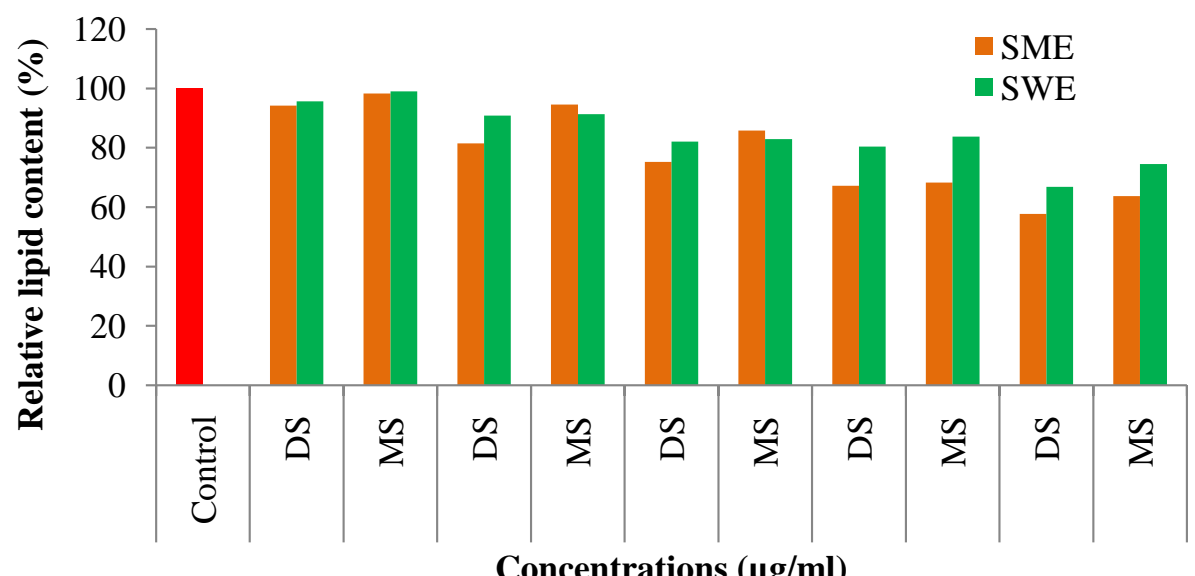

Concentrations $(\mu \mathrm{g} / \mathrm{ml})$

Figure 5. Relative lipid content post-treatment with sorrel methanol (SME) and water (SWE) extracts at differentiation stage (DS) and maintenance stage (MS). Values are Mean, $\mathrm{n}=3$. abBars not sharing common superscript are significantly different $(p<0.05)$ using Tukey’s studentized range test.

Table 2. DPPH and FRAP in sorrel methanol and water extracts.

\begin{tabular}{ccc}
\hline Sorrel & FRAP $\left(\boldsymbol{\mu m o l ~ F e} \mathbf{~}^{\mathbf{2 +}} / \mathbf{1 0 0 g}\right)$ & DPPH IC $_{50}(\mathbf{m g} / \mathbf{m l})$ \\
SME & $1799.13 \pm 71.90^{\mathrm{b}}$ & 0.82 \\
SWE & $2296.38 \pm 97.25^{\mathrm{a}}$ & 0.33 \\
\hline
\end{tabular}

FRAP: Ferric Reducing Antioxidant Power, DPPH: 1, 1-Diphenyl-2-picrylhydrazyl, SME: Sorrel methanol extracts, SWE: Sorrel water extracts. Values are Mean $\pm \mathrm{SD} ; \mathrm{n}=3 .{ }^{\text {ab }}$ Values not sharing common superscript are significantly different $(\mathrm{p}<0.05)$ using Tukey's studentized range test. 


\subsection{Triglyceride Content and Lipolysis}

Exposure of 3T3-L1 cells to SME and SWE at the differentiation and maintenance stages resulted in a decrease in triglyceride content in a concentration dependent manner (Figure 6) compared to untreated adipocytes. A significant difference in triglyceride content was observed at all tested concentrations of extracts above $600 \mu \mathrm{g} /$ $\mathrm{ml}$ except SWE treated at $600 \mu \mathrm{g} / \mathrm{ml}$ at maintenance stage. Methanol extract $(400 \mu \mathrm{g} / \mathrm{ml})$ at differentiation stage cells also resulted in significantly lower triglyceride content compared to cells treated with no sorrel extracts. Treating extracts at different stages did not show any effect in reducing the triglyceride content in water extracts. However, significant differences in lipid content at stages of treatment were observed with SME at 600 \& 800 $\mu \mathrm{g} / \mathrm{ml}$. No significant stage effect on triglyceride level was observed when cells were treated at the highest concentration. A consistent decrease in triglyceride content ranged from 6.08 to $2 \mathrm{mg} / \mathrm{dl}$ and 6.04 to $2.31 \mathrm{mg} / \mathrm{dl} \mathrm{in}$ cells treated at the differentiation stage with SME and SWE respectively. Highest $(p<0.05)(35 \%)$ decrease in triglyceride content was seen in cells exposed to SME at the differentiation stage compared to the control. Lipolytic activity of sorrel extracts in adipose tissue was determined by using glycerol release as an indicator. At each concentration tested (200 - $1000 \mu \mathrm{g} / \mathrm{ml})$, the exposure of 3T3-L1 adipocyte cells to SME and SWE at the differentiation and maintenance stages resulted in a similar release of glycerol (Figure 7). There was no stage difference found on glycerol release in adipocytes by treating sorrel extracts at all tested concentrations. Lower concentrations $(200 \& 400 \mu \mathrm{g} / \mathrm{ml})$ of both extracts did not induced significant $(\mathrm{p}<0.05)$ release of free glycerol except SME treated at $400 \mathrm{mg} / \mathrm{ml}$ differentiation stage which has significantly higher glycerol release compared untreated adipocytes. High $(600-1000 \mu \mathrm{g} / \mathrm{ml})$ concentrations of extracts at both stages induced higher $(\mathrm{p}<0.05)$ glycerol release except SWE $600 \mathrm{mg} / \mathrm{ml}$ at maintenance stage. A tenfold increase in stimulation of lipolysis was seen in cells treated with $1000 \mu \mathrm{g} / \mathrm{ml}$ at the maintenance and differentiation stages with SWE compared to the control. A 75\% glycerol release was seen in cells treated with SME at a concentration of $1000 \mu \mathrm{g} / \mathrm{ml}$ at the maintenance stage compared to the control. Highest $(\mathrm{p}<0.05)$ lipolysis was observed in cells treated with 1000 $\mu \mathrm{g} / \mathrm{ml}$ at both stages and cells treated with $800 \mathrm{mg} / \mathrm{ml}$ of SME at differentiation stage.

\subsection{Effects of Sorrel Extracts on Cell Viability}

Effect of sorrel extracts on cell viability (Figure 8) was determined by MTT assay. Treating with extracts for 8 days exhibited a moderate decrease in cell viability of adipocytes. No differences $(\mathrm{p}<0.05)$ in survival of cells were found when cell were treated with $200 \& 400 \mu \mathrm{g} / \mathrm{ml}$ of extracts at both stages compared to the control except SWE $400 \mu \mathrm{g} / \mathrm{ml}$ at differentiation stage. Incubating cells with high concentration (1000 $\mu \mathrm{g} / \mathrm{ml})$ of SWE and SME exhibited low ( $<$ 0.05) viability $(54.4 \%$ and $61.1 \%)$ of cells compared to the control. Reduction (p $<0.05)$ in viability of cell was observed at tested concentrations above $600 \mu \mathrm{g} / \mathrm{ml}$. Methanol extracts $(600 \mu \mathrm{g} / \mathrm{ml}$ and above) exhibited differences $(p<0.05)$ in viability of cells at different stages where cells treated with SME at differentiation stage exhibited lower viability compared to cells treated SME at maintenance stage. However, SWE did not show any effect on stage of treatment at the same tested concentrations. At the differentiation

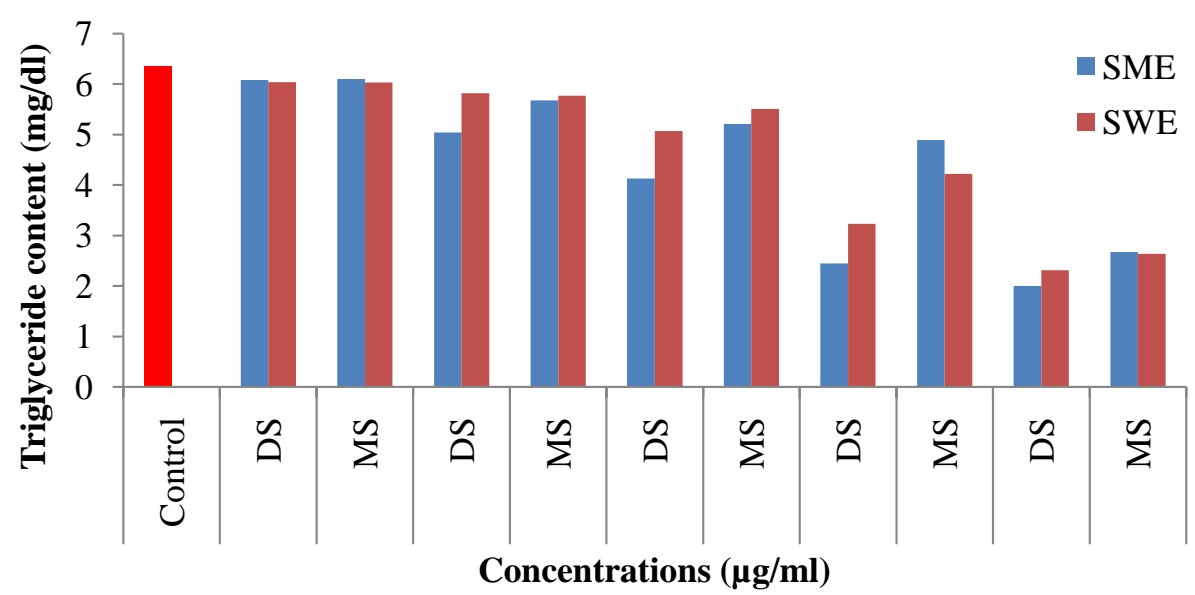

Figure 6. Effects of sorrel methanol (SME) and water (SWE) extracts on triglyceride content in 3T3-L1 cells treated at differentiation stage (DS) and maintenance stage (MS). 


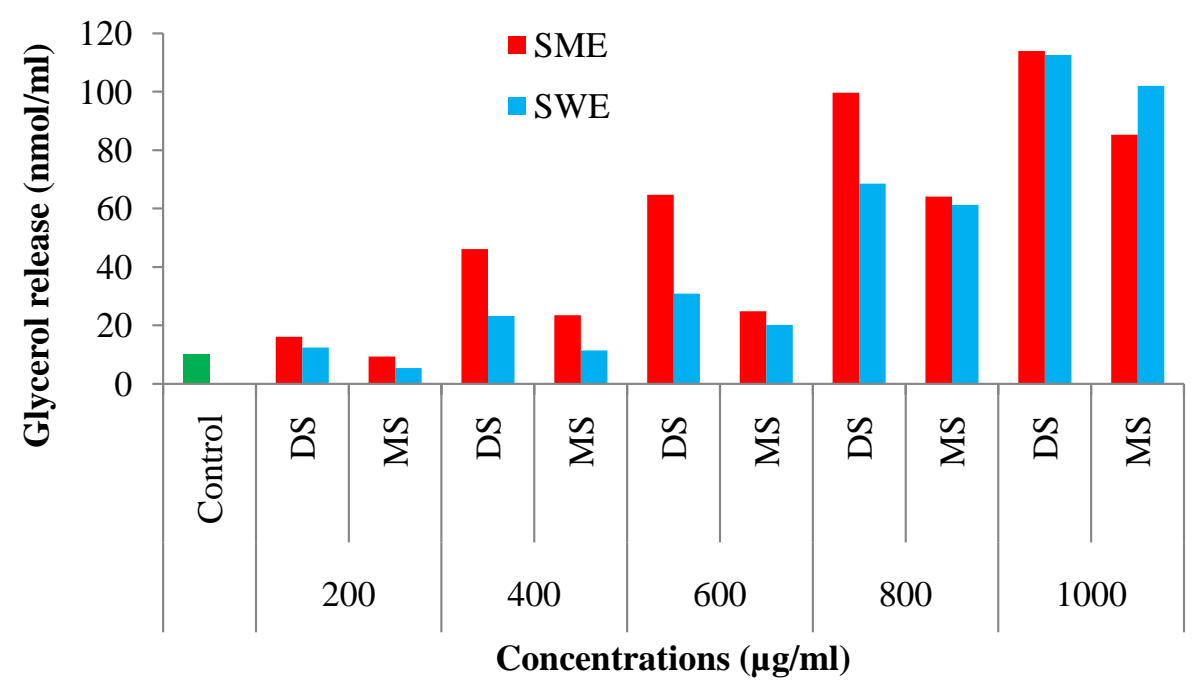

Figure 7. Effects of sorrel methanol (SME) and water (SWE) extracts on 3T3-L1 adipocyte lipolysis treated at differentiation stage (DS) and maintenance stage (MS). Values are Mean, $\mathrm{n}=$ 3 . ${ }^{a b}$ Bars not sharing common superscript are significantly different $(p<0.05)$ using Tukey’s studentized range test.

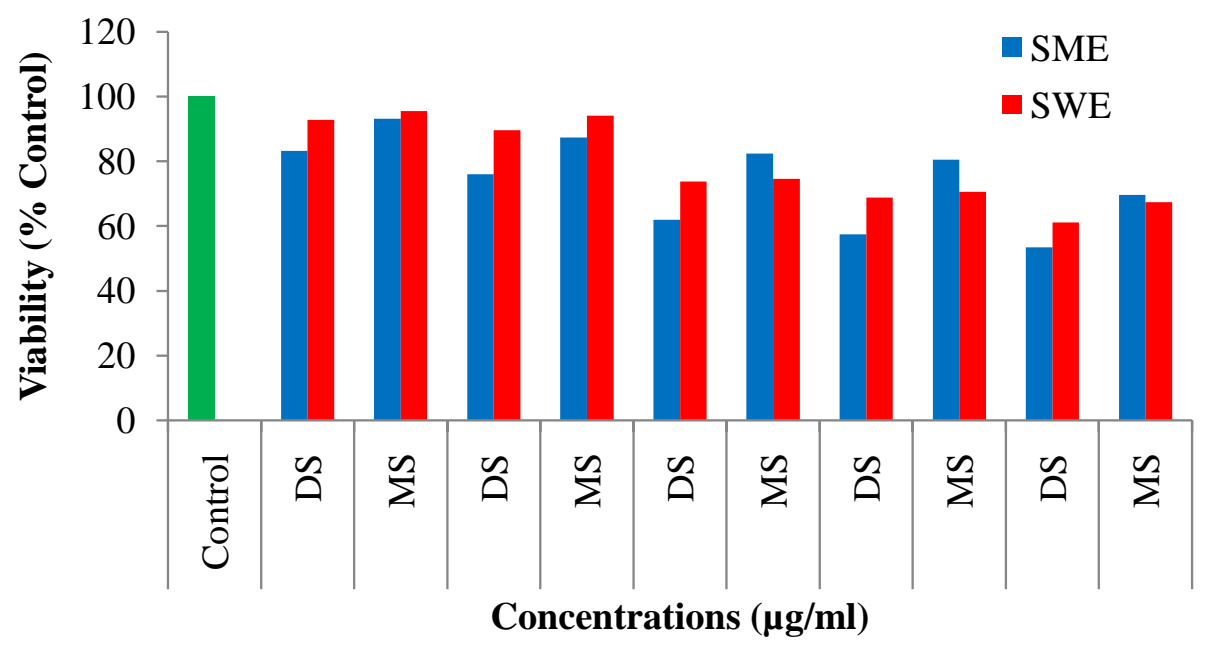

Figure 8. Effects of sorrel methanol (SME) and water (SWE) extracts on 3T3-L1 adipocyte cells viability treated at differentiation stage (DS) and maintenance stage (MS). Values are Mean, $n=3$. ${ }^{a b}$ Bars not sharing common superscript are significantly different $(\mathrm{p}<0.05)$ using Tukey's studentized range test.

stage, incubating with SME exhibited low viability at 200 - $1000 \mu \mathrm{g} / \mathrm{ml}$ compared to SWE (8\% - 39\%) at the same concentrations.

\subsection{Effect of Sorrel Extracts on Apoptosis of 3T3-L1 Adipocyte Cells}

To determine induction of apoptosis by sorrel extracts, a photometric cellular DNA fragmentation assay was conducted. Treating cells with $1000 \mu \mathrm{g} / \mathrm{ml}$ of SME at the differentiation stage caused a two fold increase in apoptosis compared to the control (Figure 9). A 3\% - 7\% lower induction of apoptosis was seen in cells treated with $200-400 \mu \mathrm{g} / \mathrm{ml}$ of SME at the differentiation stage compared to untreated adipocytes. Higher $(\mathrm{p}<0.05)$ apoptosis was observed in adipocytes treated with sorrel extracts on and above $800 \mu \mathrm{g} / \mathrm{ml}$ and also in SME 600 $\mu \mathrm{g} / \mathrm{ml}$ at maintenance stage. Treatment with extracts at different stages did not yield any significant differences in apoptosis except at highest $(1000 \mu \mathrm{g} / \mathrm{ml})$ tested concentration where, both extracts treated at differentiation 


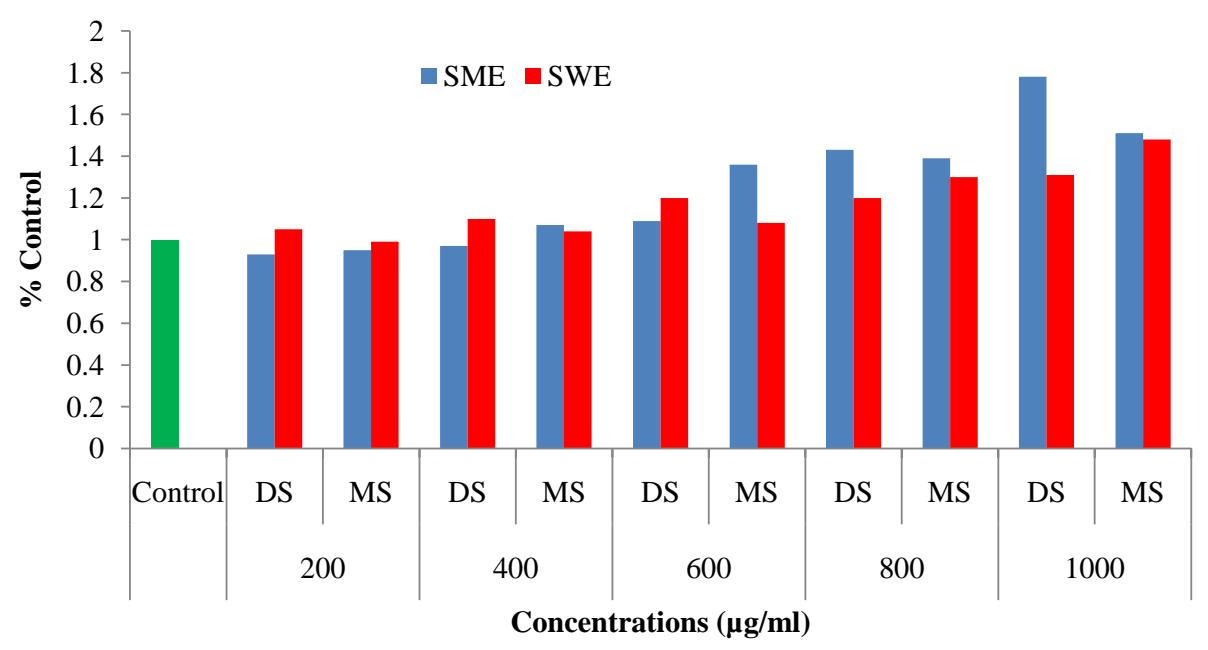

Figure 9. Effects of sorrel methanol (SME) and water (SWE) extracts on apoptosis of 3T3-L1 adipocyte cells treated at differentiation stage (DS) and maintenance stage (MS). Values are Mean, $n=3 .{ }^{a b}$ Bars not sharing common superscript are significantly different $(\mathrm{p}<0.05)$ using Tukey's studentized range test.

stage showed higher $(\mathrm{p}<0.05)$ apoptosis compared to maintenance stage. At $800 \mu \mathrm{g} / \mathrm{ml}$, a $35 \%$ increase in apoptosis was seen in cells treated with SME at the differentiation and maintenance stages compared to the control. A low but consistent increase in apoptosis was seen in cells treated with sorrel concentrations ranging from 600 to $1000 \mu \mathrm{g} / \mathrm{ml}$. Highest apoptosis in adipocytes was recorded when cells were treated with SWE at differentiation stage $(1000 \mu \mathrm{g} / \mathrm{ml})$ followed by SWE and SME at the same concentration at maintenance stage.

\subsection{Effect of Sorrel Extracts on Glycerol-3-Phosphate Dehydrogenase (GPDH) Activity}

The glycerol-3-phosphate dehydrogenase (GPDH) assay was used as a marker of late adipocyte differentiation. Marginal differences were observed in GPDH activity in 3T3-L1 adipocyte cells treated with SME and SWE $(200-1000 \mu \mathrm{g} / \mathrm{ml})$ at the differentiation and maintenance stages compared to the untreated differentiated cells (Figure 10). A 15\% - 17\% decrease in GPDH activity was seen in adipocytes treated with $1000 \mu \mathrm{g} / \mathrm{ml}$ of SME and SWE at the differentiation stage. A similar GPDH activity was seen in 3T3-L1 adipocytes treated with concentrations of SME and SWE ranging from 200 to $800 \mu \mathrm{g} / \mathrm{ml}$ compared to the control. A significant reduction ( $\mathrm{p}<$ $0.05)$ in GPDH activity was observed in cells treated with both extracts at both stages. Treating extracts at different stages did not show any effect in reducing GPDH activity.

\section{Discussion}

In the present study, we examined the anti-obesity effect of sorrel calyx extracts in 3T3-L1 cells by measuring anti-adipogenic effects and inhibitory activities of SME and SWE on obesity-related enzymes. The results showed that the solvent used in the extraction of phytochemicals affect the extractability of polyphenols present in sorrel. The higher phenolic and flavonoid contents observed in SWE compared to SME may be attributed to the high polarity and temperature of the hot water used as a solvent. A study by Prenesti et al. (2007) [29] reported similar findings on the polyphenolic contents of Hibiscus sabdariffa L. flowers extracted with water and ethanol. The higher phenolic content observed in water extracts may be attributed to the high temperature used in extraction which can accelerate the release of phenolic acids from conjugated esters, or their insoluble forms [30].

Anthocyanin pigments have been previously reported as the major source of antioxidant activity in sorrel [31]. SME yielded eight-fold higher anthocyanin content compared to SWE. Two anthocyanin pigments; delphinidin-3-sambubioside and cyanidin-3-sambubioside have been previously identified as the key contributors to sorrel antioxidant activity [32]. Results suggest that using methanol as solvent, yielded more anthocyanins in sorrel extracts compared to water.

Reducing power is commonly used as an indicator of electron-donating activity, which is an important prop- 


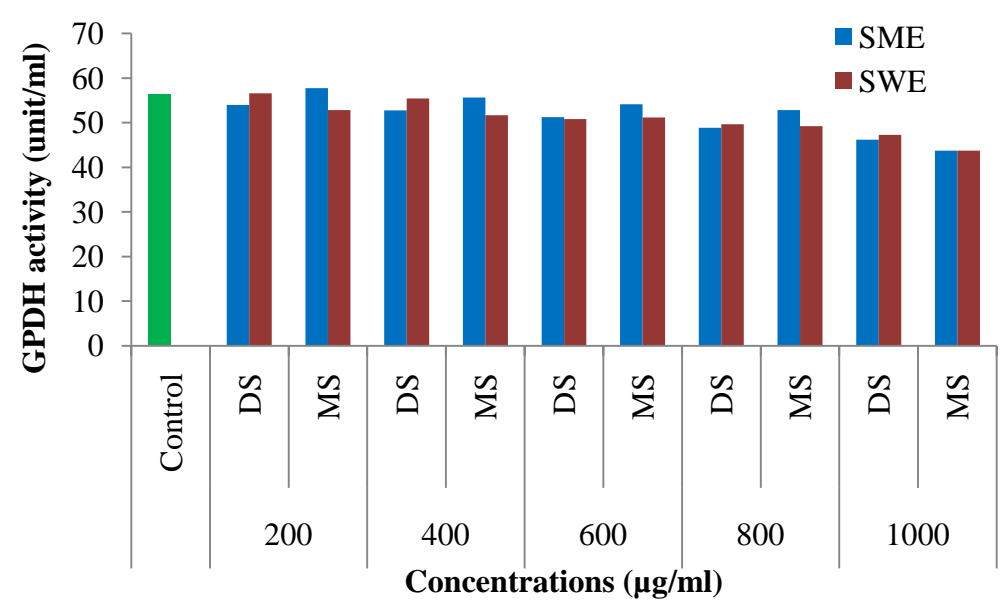

Figure 10. Effect of sorrel methanol (SME) and water (SWE) extracts on glycerol-3-phosphate (GPDH) activity treated at Differentiation stage (DS) and Maintenance stage (MS). Values are Mean, $n=3$. ${ }^{a b}$ Bars not sharing common superscript are significantly different $(\mathrm{p}<0.05)$ using Tukey's studentized range test.

erty in testing for antioxidative potential of phytochemicals [30]. In the present study, higher inhibition of DPPH radical and FRAP were seen with SWE compared to SME. The amount of polyphenolic compounds present in a plant account for its antioxidant activity [33]. The higher anti-oxidative activity of SME compared to SWE might be due to the presence of a higher polyphenolic content compared to SME. The high FRAP of sorrel extracts may be attributed to the efficacy of the major compounds found in sorrel; chlorogenic acid and its derivatives which act as reductants [34].

Inhibition of pancreatic lipase (PL) enzyme is one of the most widely studied mechanisms for determination of the potential efficacy of natural bioactive compounds as anti-obesity agents [5]. The inhibition of PL activity by SME and SWE was almost similar at all tested concentrations. The extracts of $P$. vulgaris showed PL inhibitory activity of $27.4 \%$ at a concentration of $25 \mu \mathrm{g} / \mathrm{ml}$ [35]. Our results suggest sorrel extracts have the potential to inhibit PL activity in a concentration-dependent manner. Also, the method of sorrel extractions did not have a significant effect in inhibition of PL activity.

Inhibition of enzymes involved in the hydrolysis of carbohydrates such as $\alpha$-glucosidase and $\alpha$-amylase have been exploited as a potential therapeutic approach for controlling postprandial hyper-glycemia and obesity [36]. In the present study, results showed that sorrel extracts inhibited $\alpha$-glucosidase and $\alpha$-amylase activities in a concentration-dependent manner $(0.2-4 \mathrm{mg} / \mathrm{ml})$. SME resulted in a higher percent (78\%) inhibition of $\alpha$-glucosidase activity at (4 mg/ml) compared to SWE (42\%). Moreover, SME showed higher percent (52.3\%) inhibition of $\alpha$-amylase activity compared to $38.8 \%$ at the same concentration. Studies [37] [38] indicated that hibiscus acid and cyanidin-3-glucoside present in roselle are active pancreatic $\alpha$-amylase inhibitors. Therefore, the higher inhibition of $\alpha$-amylase activity observed with SME compared to SWE may be attributed to the higher extractability of the active pancreatic $\alpha$-amylase inhibitors with a methanol solvent compared to hot water.

Adipocyte differentiation and lipid accumulation are associated with the occurrence and development of obesity [39]. In the present study, sorrel calyx extracts inhibited lipid accumulation in 3T3-L1 cells in a concentration-dependent manner. The treatment of 3T3-L1 preadipocyte cells with dietary flavonoids quercetin, kaempferol, and catechins resulted in high inhibition of adipogenesis [40]. Results from the present study suggest that both SME and SWE played a critical role in preventing adipogenesis and the accumulation of cytoplasmic lipid droplets in 3T3-L1 cells treated at the differentiation and maintenance stages.

Lipolysis in fully differentiated 3T3-L1 adipocyte cells was examined to determine whether sorrel calyx extracts reduce lipid content by increasing stimulation of glycerol release. During the differentiation stage, treatment of 3T3-L1 adipocyte cells with SME and SWE at a concentration of $1000 \mu \mathrm{g} / \mathrm{ml}$ induced a tenfold greater release of glycerol into the culture medium compared to the untreated differentiated cells. A previous study by Harmon \& Harp (2001) [41] reported similar findings with treatment of 3T3-L1 cells with genistein and epinephrine. Cells treated with SME at the differentiation stage exhibited a higher glycerol release at all tested 
concentrations (200 - $1000 \mu \mathrm{g} / \mathrm{ml}$ ) compared to cells treated at the maintenance stage. Results suggest that incubation period and the stage during the adipocyte life cycle when cells are exposed to sorrel extracts affected the amount of glycerol release. Based on the results, it is reasonable to suggest that lipolysis is one mechanism by which sorrel extracts may reduce adipose tissue mass by breaking down triacylglycerols in the 3T3-L1 adipocyte cells.

The breakdown of triacylglycerols in adipocytes and release of glycerol and fatty acids are important for the regulation of energy homeostasis [42]. In the present study, results showed a consistent decrease in triglyceride content ranging from 6.08 to $2 \mathrm{mg} / \mathrm{dl}$ and 6.04 to $2.31 \mathrm{mg} / \mathrm{dl}$ in cells treated at differentiation stage with SME and SWE respectively. The reduction in triglyceride content observed in 3T3-L1 cells may be attributed to the lipolytic activity of SME and SWE. As previously stated, SME and SWE induced lipolysis in a concentrationdepend manner with the highest glycerol release by cells treated with SME and SWE seen at $114.01 \mathrm{nmol} / \mathrm{ml}$ and $112.58 \mathrm{nmol} / \mathrm{ml}$ compared to the control $(10.12 \mathrm{nmol} / \mathrm{ml})$. Moreover, at $1000 \mu \mathrm{g} / \mathrm{ml}$, the highest inhibition of triglyceride accumulation by SME and SWE was observed at $2.0 \mathrm{nmol} / \mathrm{ml}$ and $2.31 \mathrm{nmol} / \mathrm{ml}$ compared to the control $(6.35 \mathrm{nmol} / \mathrm{ml})$. Therefore, it can be suggested that the reduction in triglyceride concentration seen in 3T3-L1 cells, may be caused by lipolytic effects of SME and SWE. In addition, a 15\% to 17\% decrease in glycerol-3-phosphate dehydrogenase (GPDH) activity was observed in cells treated with SME and SWE, which may be responsible for the lower triglyceride levels seen in 3T3-L1 adipocyte cells compared to the control.

A concentration-dependent decrease in viability was seen in 3T3-L1 adipocyte cells treated at the differentiation and maintenance stages. Percentage $(95.5 \%$ - 53.4\%) reduction in viability compared to the control was seen in 3T3-L1 adipocyte cells treated at the differentiation stage. Genistein at $200 \mu \mathrm{mol} / \mathrm{l}$ was shown to cause a $56 \%$ decrease in the viability of mature 3T3-L1 adipocytes [6]. Based on the results from the present study, it is reasonable to suggest that the effects observed on lipid accumulation, is due not only to decreased adipogenesis, but also to the effect of SME and SWE on cell viability.

The adipose tissue mass can be decreased by eliminating adipocytes through apoptosis (Kim et al., 2007). In the present study, exposure of 3T3-L1 cells to SME and SWE during the differentiation stage for a period of 6 days, showed a concentration-dependent induction of apoptosis. At lower concentrations (200 - $600 \mu \mathrm{g} / \mathrm{ml}$ ), sorrel extracts did not show apoptotic effects. However, an approximately two-fold increase in induction of apoptosis was seen in cells treated with $1000 \mu \mathrm{g} / \mathrm{ml}$ of SME at the differentiation stage. Results suggest that sorrel extracts may be used to decrease adipose tissue mass through apoptosis.

\section{Conclusion}

Hibiscus sabdariffa L. (sorrel) contains bioactive compounds that are important in modulating obesity through anti-oxidant related mechanisms and inhibition of adipogenesis in 3T3-L1 adipocyte cells. The inhibition of pancreatic lipase, $\alpha$-glucosidase, and $\alpha$-amylase activities (in-vitro) by SME and SWE may provide a potential means of developing safe therapeutic approaches of preventing and/or treating obesity. The inhibition of lipid accumulation and intracellular triglyceride accumulation in 3T3-L1 adipocyte cells by SME and SWE may suggest that sorrel extracts play a critical role in preventing adipogenesis and reducing accumulation of cytoplasmic lipid droplets. This is important in preventing development of obesity by decreasing hyperplasia and hypertrophy of white adipocyte cells. Based on the results, treatment of 3T3-L1 cells with SME and SWE stimulate lipolysis. The induction of apoptosis in 3T3-L1 cells by SME and SWE was low, suggesting that other mechanisms might be responsible for the decrease in number of 3T3-L1 adipocyte cells.

\section{Acknowledgements}

Funding was provided by the Alabama Agricultural Experiment Research Station, USDA Evans Allen Grant.

\section{References}

[1] Marinou, K., Tousoulis, D., Antonopoulos, A.S., Stefanadi, E. and Stefanadis, C. (2010) Obesity and Cardiovascular Disease: From Pathophysiology to Risk Stratification. International Journal of Cardiology, 138, 3-8. http://dx.doi.org/10.1016/j.ijcard.2009.03.135

[2] Matsuo, T., Matsuo, M., Kasai, M. and Takeuchi, H. (2001) Effects of a Liquid Diet Supplement Containing Structured Medium- and Long-Chain Triacylglycerols on Body Fat Accumulation in Healthy Young Subjects. Asia Pac Journal of Clinical Nutrition, 10, 46-50. http://dx.doi.org/10.1046/j.1440-6047.2001.00196.x 
[3] Kim, J.K., So, H., Youn, M.J., Kim, H.J., Kim, Y., Park, C. and Park, R. (2007) Hibiscus sabdariffa L. Water Extract Inhibits the Adipocyte Differentiation through the PI3-K and MAPK Pathway. Journal of Ethnopharmacology, 114, 260-267. http://dx.doi.org/10.1016/j.jep.2007.08.028

[4] MacDougald, O.A. and Mandrup, S. (2002) Adipogenesis: Forces That Tip The Scales. Trends Endocrinol Metabolism, 13, 5-11. http://dx.doi.org/10.1016/S1043-2760(01)00517-3

[5] Birari, R.B. and Bhutani, K.K. (2007) Pancreatic Lipase Inhibitors From Natural Sources: Unexplored Potential. Drug Discovery Today, 12, 879-889. http://dx.doi.org/10.1016/j.drudis.2007.07.024

[6] Rayalam, S., Della-Fera, M.A. and Baile, C.A. (2008) Phytochemicals and Regulation of the Adipocyte Life Cycle. The Journal of Nutritional Biochemistry, 19, 717-726. http://dx.doi.org/10.1016/j.jnutbio.2007.12.007

[7] Foster-Schubert, K.E. and Cummings, D.E. (2006) Emerging Therapeutic Strategies for Obesity. Endocrine Reviews, 27, 779-793. http://dx.doi.org/10.1210/er.2006-0041

[8] Shi, Y. and Burn, P. (2004) Lipid Metabolic Enzymes: Emerging Drug Targets for the Treatment of Obesity. Nature Reviews Drug Discovery, 3, 695-710. http://dx.doi.org/10.1038/nrd1469

[9] Strader, C.D., Hwa, J.J., Van Heek, M. and Parker, E.M. (1998) Novel Molecular Targets for the Treatment of Obesity. Drug Discovery Today, 3, 250-256. http://dx.doi.org/10.1016/S1359-6446(98)01189-1

[10] Mukherjee, M. (2003) Human Digestive and Metabolic Lipases-A Brief Review. Journal of Molecular Catalysis B: Enzymatic, 22, 369-376. http://dx.doi.org/10.1016/S1381-1177(03)00052-3

[11] Thomson, A.B.R., De Pover, A., Keelan, M., Jarocka-Cyrta, E. and Clandinin, M.T. (1997) Inhibition of Lipid Absorption as an Approach to the Treatment of Obesity. Methods in Enzymology, 286, 3-44. http://dx.doi.org/10.1016/S0076-6879(97)86003-X

[12] Tsujita, T., Ninomiya, H. and Okuda, H. (1989) p-Nitrophenyl Butyrate Hydrolyzing Activity of Hormone-Sensitive Lipase from Bovine Adipose Tissue. Journal of Lipid Research, 30, 997-1004.

[13] Krentz, A.J. and Bailey, C.J. (2005) Oral Antidiabetic Agents. Drugs, 65, 385-411. http://dx.doi.org/10.2165/00003495-200565030-00005

[14] Lebovitz, H.E. (1998) Postprandial Hyperglycaemic State: Importance and Consequences. Diabetes Research and Clinical Practice, 40, S27-S28.

[15] Watanabe, J., Kawabata, J., Kurihara, H. and Niki, R. (1997) Isolation and Identification of $\alpha$-Glucosidase Inhibitors from Tochu-Cha (Eucommia ulmoides). Bioscience, Biotechnology, and Biochemistry, 61, 177-178. http://dx.doi.org/10.1271/bbb.61.177

[16] Yoshikawa, M., Murakami, T., Yashiro, K. and Matsuda, H. (1998) Kotalanol, a Potent $\alpha$-Glucosidase Inhibitor with Thiosugar Sulfonium Sulfate Structure, from Antidiabetic Ayurvedic Medicine Salacia reticulata. Chemical and Pharmaceutical Bulletin, 46, 1339-1340. http://dx.doi.org/10.1248/cpb.46.1339

[17] González-Castejón, M. and Rodriguez-Casado, A. (2011) Dietary Phytochemicals and Their Potential Effects on Obesity: A Review. Pharmacological Research, 64, 438-455. http://dx.doi.org/10.1016/j.phrs.2011.07.004

[18] Morton, J.F. (1987) Roselle, Hibiscus sabdariffa L. In: Morton, J.F., Ed., Fruits of Warm Climates, Miami, $281-286$.

[19] Haji Faraji, M. and Haji Tarkhani, A. (1999) The Effect of Sour Tea (Hibiscus sabdariffa) on Essential Hypertension. Journal of Ethnopharmacology, 65, 231-236. http://dx.doi.org/10.1016/S0378-8741(98)00157-3

[20] Adom, K.K. and Liu, R.H. (2002) Antioxidant Activity of Grains. Journal of Agricultural and Food Chemistry, 50, 6182-6187. http://dx.doi.org/10.1021/jf0205099

[21] Singleton, V.L., Orthofer, R. and Lamuela-Raventos, R.M. (1999) Analysis of Total Phenols and Other Oxidation Substrates and Antioxidants by Means of Folin-Ciocalteu Reagent. Methods in Enzymology, 299, 152-178. http://dx.doi.org/10.1016/S0076-6879(99)99017-1

[22] Kim, D.O., Jeong, S.W. and Lee, C.Y. (2003) Antioxidant Capacity of Phenolic Phytochemicals from Various Cultivars of Plums. Food Chemistry, 81, 321-326. http://dx.doi.org/10.1016/S0308-8146(02)00423-5

[23] Lee, J., Durst, R.W. and Wrolstad, R.E. (2005) Determination of Total Monomeric Anthocyanin Pigment Content of Fruit Juices, Beverages, Natural Colorants, and Wines by the pH Differential Method: Collaborative Study. Journal of AOAC International, 88, 1269-1278.

[24] Bondet, V., Brand-Williams, W. and Berset, C. (1997) Kinetics and Mechanisms of Antioxidant Activity Using the DPPH Free Radical Method. LWT-Food Science and Technology, 30, 609-615. http://dx.doi.org/10.1006/fstl.1997.0240

[25] Benzie, I.F. and Strain, J.J. (1999) [2] Ferric Reducing/Antioxidant Power Assay: Direct Measure of Total Antioxidant Activity of Biological Fluids and Modified Version for Simultaneous Measurement of Total Antioxidant Power and Ascorbic Acid Concentration. Methods in Enzymology, 299, 15-27. http://dx.doi.org/10.1016/S0076-6879(99)99005-5 
[26] Won, S.R., Kim, S.K., Kim, Y.M., Lee, P.H., Ryu, J.H., Kim, J.W. and Rhee, H.I. (2007) Licochalcone A: A Lipase Inhibitor from the Roots of Glycyrrhiza uralensis. Food Research International, 40, 1046-1050. http://dx.doi.org/10.1016/j.foodres.2007.05.005

[27] Kim, H., Hiraishi, A., Tsuchiya, K. and Sakamoto, K. (2010) Epigallocatechin Gallate Suppresses the Differentiation of 3T3-L1 Preadipocytes through Transcription Factors FoxO1 and SREBP1c. Cytotechnology, 62, 245-255. http://dx.doi.org/10.1007/s10616-010-9285-X

[28] Suryawan, A. and Hu, C.Y. (1993) Effect of Serum on Differentiation of Porcine Adipose Stromal-Vascular Cells in Primary Culture. Comparative Biochemistry and Physiology Part A: Physiology, 105, 485-492. http://dx.doi.org/10.1016/0300-9629(93)90424-3

[29] Prenesti, E., Berto, S., Daniele, P.G. and Toso, S. (2007) Antioxidant Power Quantification of Decoction and Cold Infusions of Hibiscus sabdariffa Flowers. Food Chemistry, 100, 433-438. http://dx.doi.org/10.1016/j.foodchem.2005.09.063

[30] Terpinc, P., Polak, T., Makuc, D., Ulrih, N.P. and Abramovič, H. (2012) The Occurrence and Characterisation of Phenolic Compounds in Camelina sativa Seed, Cake and Oil. Food Chemistry, 131, 580-589. http://dx.doi.org/10.1016/j.foodchem.2011.09.033

[31] Tsai, P.J., McIntosh, J., Pearce, P., Camden, B. and Jordan, B.R. (2002) Anthocyanin and Antioxidant Capacity in Roselle (Hibiscus sabdariffa) Extract. Food Research International, 35, 351-356. http://dx.doi.org/10.1016/S0963-9969(01)00129-6

[32] Christian, K.R., Nair, M.G. and Jackson, J.C. (2006) Antioxidant and Cyclooxygenase Inhibitory Activity of Sorrel (Hibiscus sabdariffa). Journal of Food Composition and Analysis, 19, 778-783. http://dx.doi.org/10.1016/j.jfca.2006.04.004

[33] Yen, G.C., Duh, P.D. and Tsai, H.L. (2002) Antioxidant and Pro-Oxidant Properties of Ascorbic Acid and Gallic Acid. Food Chemistry, 79, 307-313. http://dx.doi.org/10.1016/S0308-8146(02)00145-0

[34] De Leonardis, A., Pizzella, L. and Macciola, V. (2008) Evaluation of Chlorogenic Acid and Its Metabolites as Potential Antioxidants for Fish Oils. European Journal of Lipid Science and Technology, 110, 941-948. http://dx.doi.org/10.1002/ejlt.200700317

[35] Zhang, J., Kang, M.J., Kim, M.J., Kim, M.E., Song, J.H., Lee, Y.M. and Kim, J.I. (2008) Pancreatic Lipase Inhibitory Activity of Taraxacum officinale in Vitro and in Vivo. Nutrition Research and Practice, 2, 200-203. http://dx.doi.org/10.4162/nrp.2008.2.4.200

[36] Shim, Y.J., Doo, H.K., Ahn, S.Y., Kim, Y.S., Seong, J.K. and Park, I.S. (2003) Inhibitory Effect of Aqeous Extract from the Gal of Rhuz chinesis on Alpha-Lucosidase Activities and Postprandial Blood Glucose. Journal of Ethnopharmacology, 85, 283-287. http://dx.doi.org/10.1016/S0378-8741(02)00370-7

[37] Hansawasdi, C., Kawabata, J. and Kasai, T. (2001) Hibiscus Acid as an Inhibitor of Starch Digestion in the Caco-2 Cell Model System. Bioscience, Biotechnology, and Biochemistry, 65, 2087-2089. http://dx.doi.org/10.1271/bbb.65.2087

[38] Akkarachiyasit, S., Charoenlertkul, P., Yibchok-Anun, S. and Adisakwattana, S. (2010) Inhibitory Activities of Cyanidin and Its Glycosides and Synergistic Effect with Acarbose against Intestinal $\alpha$-Glucosidase and Pancreatic $\alpha$-Amylase. International Journal of Molecular Sciences, 11, 3387-3396. http://dx.doi.org/10.3390/ijms11093387

[39] Fève, B. (2005) Adipogenesis: Cellular and Molecular Aspects. Best Practice \& Research Clinical Endocrinology \& Metabolism, 19, 483-499. http://dx.doi.org/10.1016/j.beem.2005.07.007

[40] Chien, P.J., Chen, Y.C., Lu, S.C. and Sheu, F. (2005) Dietary Flavonoids Suppress Adipogenesis in 3T3-L1 Preadipocytes. Journal of Food and Drug Analysis, 13, 168-175.

[41] Harmon, A.W. and Harp, J.B. (2001) Differential Effects of Flavonoids on 3T3-L1 Adipogenesis and Lipolysis. American Journal of Physiology. Cell Physiology, 280, C807-C813.

[42] Frayn, K.N., Karpe, F., Fielding, B.A., Macdonald, I.A. and Coppack, S.W. (2003) Integrative Physiology of Human Adipose Tissue. International Journal of Obesity, 27, 875-888. http://dx.doi.org/10.1038/sj.ijo.0802326 